\title{
The RPTRA Geographic Information System Application in Central Jakarta City Using the Dijkstra Algorithm Based on Android
}

\author{
Danur Sugiharja $1^{\text {st }}$ \\ STMIK Nusa Mandiri \\ Jakarta, Indonesia \\ dsugiharja@gmail.com
}

\author{
Omar Pahlevi $2^{\text {nd }}$ \\ Universitas Bina Sarana Informatika \\ Jakarta, Indonesia \\ omar.opi@bsi.ac.id
}

\author{
Reni Widyastuti $3^{\text {rd }}$ \\ Universitas Bina Sarana Informatika \\ Jakarta, Indonesia \\ reni.rws@bsi.ac.id
}

\begin{abstract}
Child Friendly Integrated Public Space or also known by the abbreviation RPTRA is the concept of public space in the form of green open spaces or parks that are equipped with various interesting games. Currently RPTRA is already widely available in all DKI Jakarta, especially in Central Jakarta, but there are still many people who do not know the location of the location of RPTRA. The dijkstra algorithm applied to this Android-based RPTRA geographic information system application in the City of Central Jakarta is to use google maps as a navigation map, where the Algorithm: \{When users select the Map menu in the main menu, users will see maps and points of all RPTRA locations in Central Jakarta City, select one of the RPTRA location points, after the user selects one RPTRA location point, select the image on the right bottom route, then the user will go to google maps to get the route to the selected RPTRA. \} The location of RPTRA directly takes coordinates at each RPTRA located in Central Jakarta City. The results achieved in testing the application went well able to provide accurate data on the location points of RPTRA in Central Jakarta.
\end{abstract}

\section{Keywords - Geographic Information System, RPTRA Central Jakarta City, Dijkstra Algorithm, Android}

\section{INTRODUCTION}

Today's technology has experienced very high progress, especially on smartphones today. The latest breakthrough in smartphones is marked by the emergence of an operating system, namely Android. Android is a software platform for mobile devices that is supported by Google OS (Kusuma, 2013). Mobile technology has several advantages, one of the advantages of mobile technology today is the Mobile GIS (Geographic Information System) technology that has installed Location Based Service technology (Rizal, 2017). This makes it easier for developers to take advantage of the geographical values of GPS technology which are coordinates for developing LBS-based applications (Lengkong, 2015).
Currently there are many Geographic Information System (GIS) applications that can be combined with smartphones because in general new output smartphone devices already have GPS features so information can be obtained anywhere and anytime (Rianto, 2015). GPS (Global Positioning System) is a system for finding the location on the surface of the earth with the help of synchronizing satellite signals (Putra, 2014).

Child Friendly Integrated Public Space (RPTRA) is a park built by the DKI Jakarta Provincial Government for the community. But unfortunately many people do not know the location of the RPTRA. Therefore the RPTRA Geographic Information System (GIS) application was made in Central Jakarta using the dijkstra algorithm. The use of technology and assisted with Global Positioning System (GPS) technology which functions as a 
pointer to the current location, Location Based Service (LBS) that provides information based on the geographical location of mobile devices, as well as available Google Maps API facilities.

This research is similar to the previous research, namely (Kurniawan, 2015) explaining that the implementation of Geographic Information Systems Searching for the Nearby Bus and Travel Agent Locations in Semarang city aims to build an Android-based Geographic Information System application. In this study using the dijkstra algorithm as a search method, location data retrieval uses the GPS feature provided to help users from the user's device location by comparing the distance between the user's device to the related nodes so that this software can provide an efficient and efficient route. saving time.

Research conducted by (Fahmi, 2018) explains that the use of Geographical Information Systems can process hotel data and produce information about hotels such as short hotel profiles, map visualization of the hotel geographical location and the route to the hotel in Majalengka. In the development of this application using the dijkstra algorithm in the design of the user interface page search route, where this page serves to display the route sought by the user by determining the starting point of departure and the hotel you want to go to.

In this study using the dijkstra algorithm applied to the RPTRA geographic information system application in Central Jakarta by utilizing Google Maps as a navigation map, for example when a user selects the Map menu in the main menu, the user will see maps and points from all RPTRA locations in Central Jakarta City, select one of the RPTRA location points, after the user selects one RPTRA location point, select the image on the right bottom route, then the user will go to Google Maps to get the route to the selected RPTRA.

\section{Literature REVIEW}

\section{A. Geographic Information System}

According to (Suryamen, 2016) defining Geographic Information Systems is a tool with a computer system that is used to plague the conditions and events that occur on earth. This GIS technology can integrate database operating systems such as queries and statistical analysis with various advantages of geographical analysis offered in map form. With capabilities in the mapping information system (spatial information) that distinguishes it from other information systems such as databases, GIS is widely used by society, entrepreneurs and agencies explain events, predict results and strategic planning.

\section{B. Android}

According to (Yosef, 2014) explained that "Android is a Linux-based operating system that is used for cellular (mobile) phones such as shortcuts (smartphones) and tablet computers (PDAs)".

\section{Google maps API}

According to (Juanyah, 2015) explained that Google Maps is a service from Google that makes it easier for users to perform mapping capabilities for applications that are made. A Google Maps API allows development to integrate Google Maps into a website. Using the Google Maps API allows to embed Google Maps sites into external sites, where certain data sites can be overlaid.

\section{Location Based Service (LBS)}

According to (Milzan, 2016) explains that Location Based Service (LBS) is a general term used to describe the technology used to find the location of the device we are using.

\section{E. Dijkstra's Algorithm}

According to (Rumenser, 2014) explained that the Dijkstra algorithm is an algorithm for determining the shortest distance from a vertex to another vertex on a weighted graph, where the distance between vertices is the weight of each edge on the graph. The Dijkstra algorithm looks for the shortest distance from the origin vertex to the shortest vertex from the origin of the origin vertex to the closest vertex, then to the second vertex, and so on.

\section{Proposed Method}

\section{F. Object Research}

This research was conducted by collecting data through the results of interviews and location point data that have been collected through official data available on the page http://www.data.jakarta.go.id.

\section{G. System Development Methods}

The system development method used in this study is the waterfall method. (Suryamen, 2016) describes the stages of the waterfall method as follows: 


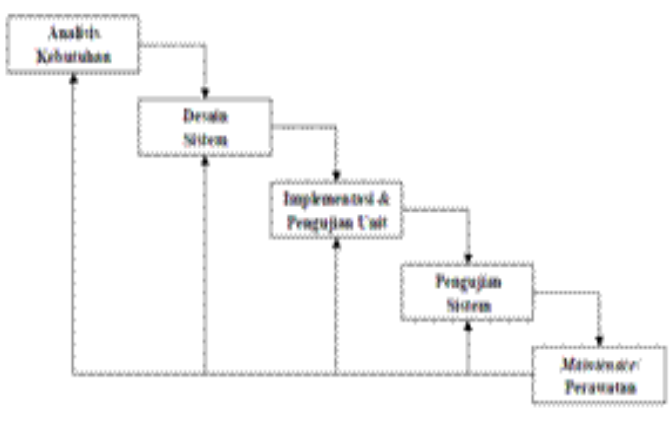

Figure 1. Stages of the Waterfall Method

\section{a. Needs Analysis}

At this stage the researcher conducts complete analysis and data collection. Data has been collected through the results of interviews and location point data that have been collected through official data available on the page http://www.data.jakarta.go.id

\section{b. System Design}

The next step is designing a system that will describe the functionalities of the system to be built as a whole. The RPTRA Geographic Information System is built on Android and uses a basic Google Maps map.

\section{c. Unit Implementation and Testing}

After the system design is complete, what is done next is to do a program code research. The software used by researchers to write program code is Android Studio and uses the XML program language (eXtensible Markup Language) and Java Modeling.

\section{d. System Testing}

System testing is carried out which aims to ensure that the functional application is in accordance with the needs.

\section{e. Maintenance}

At this stage the program which has been tested and stated fulfill the qualification requirements will be implemented directly to the user.

\section{RESUlt AND Discussion}

The algorithm used in this study is the dijkstra algorithm, where the dijkstra algorithm applied to the RPTRA geographic information system application in Central Jakarta City is by utilizing Google Maps as a navigation map, for example:

Algorithm: \{When a user selects the Map menu in the main menu, users will see maps and points from all RPTRA locations in Central Jakarta City, select one of the RPTRA location points, after the user selects one RPTRA location point, select the bottom right route picture, then the user will go to Google Maps to get the route to the selected RPTRA. \}

The following are the interface displays of the application

a. Display of RPTRA Maps

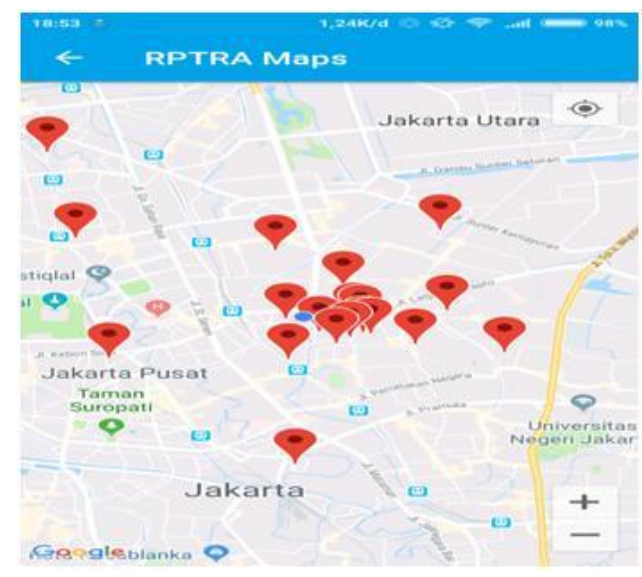

Figure 2. Display of RPTRA Maps

The RPTRA Maps view contains the RPTRA location points in the city of Central Jakarta.

b. Display of road guide / navigation pages

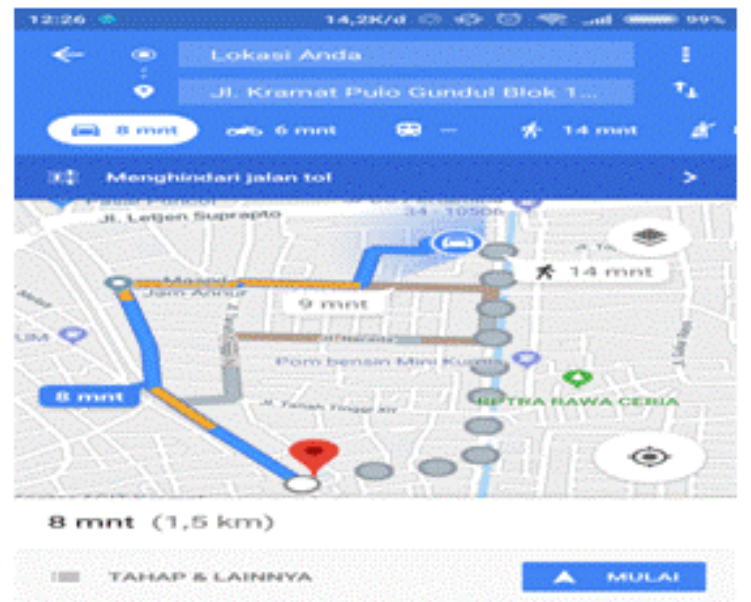

Figure 3. Display of road guide / navigation pages

In the display of road guidance / navigation in the form of a route from Google Maps which is the shortest distance to get to the location of RPTRA. Display this guide / navigation, to help users to go to the location of RPTRA. This navigation is directly connected to Google Maps to get the shortest route. 
This study uses cyclomatic white box testing.

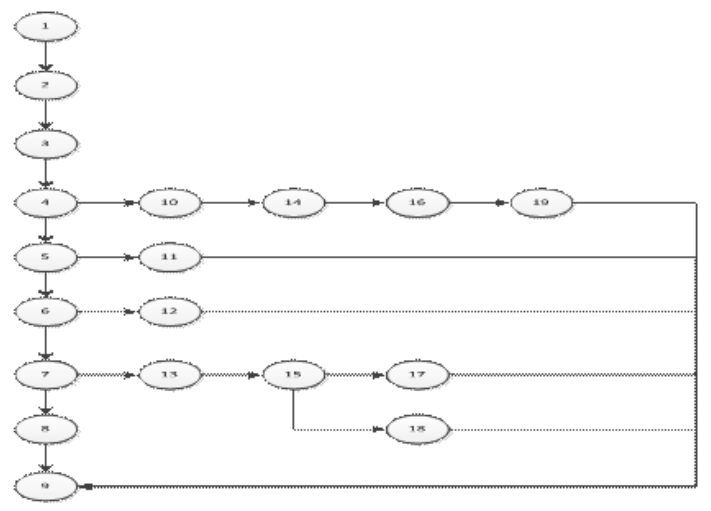

Figure 4. Cyclomatic white box testing

In this test, the researcher calculates the cyclical complexity of the white box flow chart, which can be obtained as follows:

$\mathrm{V}(\mathrm{G})=\mathrm{E}-\mathrm{N}+2$

Where :

$\mathrm{E}=$ The specified Edge number of arrow images

$\mathrm{N}=$ The number of node flow charts is determined by a circle image

$\mathrm{V}(\mathrm{G})=23-19+2=6$

$\mathrm{V}(\mathrm{G})<10$ means to qualify for cyclical complexity. The set lines generated by the independent path are as follows:

1) 1-2-3-4-10-14-16-19-9

2) $1-2-3-4-5-11-9$

3) 1-2-3-4-5-6-12-9

4) 1-2-3-4-5-6-7-13-15-17-9

5) $1-2-3-4-5-6-7-13-15-18-9$

6) 1-2-3-4-5-6-7-8-9

In this application there are several samples tested, namely the white box testing of the SIG RPTRA application in Central Jakarta City. The algorithm is:

a) Select the Map menu in the main menu, then the user will enter the RPTRA Maps page and display all RPTRA location points in Central Jakarta.

b) Users can choose one location point and the RPTRA name and RPTRA address will appear.

c) Select the navigation image below the right after selecting a location point, to get the route through Google Maps. d) The route obtained through Google Maps is the shortest route from Google Maps.

The results achieved in testing the application went well able to provide accurate data on the location points of RPTRA in Central Jakarta

\section{CONClusion AND SUgGeSTION}

Based on the results of the explanation and discussion of the RPTRA Graphic Information System Application in Central Jakarta City, conclusions can be obtained:

1. The application that was made was able to fulfill the need to carry out the process of searching RPTRA in the City of Central Jakarta from a mobile device by providing a fairly accurate RPTRA position.

2. The RPTRA search application in Central Jakarta City can display the route to RPTRA via Google Maps.

3. The dijkstra algorithm used in this study utilizes Google Maps to get road directions or the shortest route to get to the RPTRA location.

The suggestions from researchers are

1. Adding the location of RPTRA to the whole of DKI Jakarta.

2. Add the distance feature using the RPTRA list haversine algorithm to find out the closest RPTRA distance.

\section{ACKNOWLEDGMENT}

We would like to take this opportunity to thank all contributors of this journal. A special thanks to Dr. Mochamad Wahyudi, MM, M.Kom, M.Pd for his invaluable encouragement, guidance and support. Not forgetting also a big thanks to the team of the Journal SINKRON Politeknik Ganesha, Medan.

\section{REFERENCES}

Implementasi Sistem Informasi Geografis Penentuan Rute Hotel Terdekat Menggunakan Algoritma Dijkstra Di Kab. Majalengka 2018 Infotech Journal Universitas Majalengka

Pembangunan Aplikasi Child Tracker Berbasis Asissted-Global Positioning System (A-GPS) Dengan Platform Android 2015 Jurnal Ilmiah Komputer dan Informatika (KOMPUTA) Universitas Komputer Indonesia

Sistem Informasi Geografis Pencarian Lokasi Agen Bus Dan Travel Terdekat Di Kota Semarang Berbasis Mobile Dengan Metode Dijkstra 2015 Jurnal Teknologi dan Sistem Komputer Universitas Diponegoro 
Aplikasi Location Based Service (LBS) Taman Mini Indonesia Indah (TMII) Berbasis Android 2013 Seminar Nasional Aplikasi Teknologi Informasi (SNATI)

Perancangan Penunjuk Rute Pada Kendaraan Pribadi Menggunakan Aplikasi Mobile GIS Berbasis Android Yang Terintegrasi Pada Google Maps 2015 E-Journal Teknik Elektro Dan Komputer

Sistem Informasi Geografis Tour Dan Travel Berbasis Android Di Kabupaten Tegal 2016 Jurnal Teknologi Dan Sistem Komputer

Pengembangan Aplikasi Peta Wisata Garut Berbasis Android Menggunakan Metode Rapid Application Development 2014 Jurnal Algoritma

Perancangan Aplikasi Sistem Informasi Geografis (SIG) Lokasi Minimarket Di Kota Jambi Berbasis Android 2015 Jurnal Ilmiah Media SISFO

Perancangan Aplikasi Lokasi Wisata Kota Jakarta Menggunakan Algoritma Sequential Search Berbasis Android 2017 Jurnal Pilar Nusa Mandiri

Sistem Informasi Geografis Berbasis Web Untuk Menentukan Rute Tercepat Dengan Algoitma Dijkstra Di Kota Gorontalo 2014 Universitas Negeri Gorontalo

Perancangan Sistem Informasi Geografis Lapangan Futsal Kota Padang Berbasis Web 2016 TEKNOSI

Android Black Box 2014 Jasakom 